\title{
GENDERING DEATH AND RENEWAL: CLASSICAL MONUMENTS OF THE FIRST WORLD WAR
}

\section{ANA CARDEN-COYNE}

$C_{\text {t }}^{1}$ lassical motifs have a long and triumphant heritage in war monuments and memorials. In the aftermath of the First World War, memorial designers appeared to return to the tropes and symbols of classicism in their search for appropriate forms to commemorate the war dead. On the one hand, classicism reflected the language and ideals of imperialist imagination, so deeply enmeshed within Victorian and Edwardian thinking. Conversely, the utopic potential of classical harmony and simplicity lent a different kind of ritualised significance to the personal, social and political process that is commemoration. Arguably, this latter shift was an outcome of the scale and type of injuries that human bodies incurred in this first global, mechanised and mass form of warfare. Investigating the embodied meaning of memorial architecture, this essay considers the gendered meaning of war and recovery as it appeared in some key war monuments of the postwar period.

Classical monuments of the First World War narrated war and peace. In doing so, classicism was not revived in purely literal or mimetic ways. Executed with a range of traditional and innovative approaches, postwar classicism projected something of the experience of mass warfare and its entanglement with modernity. ${ }^{1}$ This essay argues that the coalition between the classical and modern in war monuments is pertinent to understanding the impact of war and the ongoing search for healing through cultural practices. In contrast to the catharsis of much war art and literature, what Jay Winter refers to as 'the apocalyptic imagination', classical memorials attempted to act as an antidote to the trauma of war. ${ }^{2}$ I use this phrase not just to recall the reciprocity between monuments, bereaved and damaged individuals, and mourning communities, but in order to suggest the role of commemorative architecture as an alternative body to that killed, injured or disabled by war, and thus also to suggest the 'performative' aspect of gender in its use of figuration. Although this idea of gender as performed is usually reserved for real people, if we consider embodiment an underlying principle in war monuments then this analytical structure may also be useful. ${ }^{3}$

Classicism convened a powerful language of the noble, ideal and spiritual, but most of all the supremely corporeal. Circumventing the horrors of the recent past, the body was reinvented through architectural forms. These memorials enacted a form of rehabilitation in the corporeal sense, providing a vision of wholeness and restoration that displaced the body violated by war. The corporeality of classical war monuments lent 
itself to a profoundly gendered representation of death as masculine and beautiful, and the renewal of life in peacetime, as feminine and maternal. The relationship between war and peace, death and renewal, was comparable to the gendering of space. The notion of a partnership was crucial here. The architectural body was set as a companion to bodily memories of war. Since classicism performed a technique of distancing, by evoking timelessness, universality, longevity, it presented an alternative version of time to that of the immediate traumatic past. It helped to create an alternative memory of war, which, as Pierre Nora has powerfully argued, encouraged collective amnesia or a displacement of memory. ${ }^{4}$ It should not, however, be reduced to a mere political process of reconstruction, or a collusion to forget. Rather, classical symbolism became an associate to war, providing an image of peace that was a partner to war. War, then, was not diminished, but rather naturalised as part of a universal cycle, sitting comfortably alongside the image and political meaning of peace. The classical metaphor was highly useful in the production of a companionate memory that accompanied the embodied structures of monuments. I want to suggest that this production of both war and peace was something of a social, political and aesthetic marriage, and as such was profoundly gendered. The gendering of this embodiment occurs in the image of War as masculine and the image of Peace as feminine. First, in numerous images of the male body as a sleeping model of the 'beautiful death' accomplished in by war heroes. Second, in the use of an ideal and allegorical body, especially in the form of a Nike or Winged Victory.

In the Homeric songs a warrior's passage to heroic immortality occurs when he 'dies young and stays pretty'. What the ancients referred to as 'beautiful death' (kalos thanatos), invoked the ideals of noble sacrifice bound up with the beauty of youthful masculinity, which was mythologised into a culture of the warrior hero. ${ }^{5}$ Given that the love between men is the highest in the Homeric warrior tradition, it is not too surprising that men experience the beauty of death because it binds them together, it affirms the gender of death and the beauty of a masculinity cut short in its prime, in the pursuit of fame, glory and eternal youth.

There are some remarkable convergences with the way the dead were heroised after the First World War. Ambrose Pratt, for instance, replayed Homeric heroism in his interpretation of the Melbourne Shrine of Remembrance and the role of the Anzacs in the war. Like the 'gallant hosts of Troy', he wrote, the Anzacs went to war 'not in lust of conquest or in hope of gain, but to rectify a wrong, to vindicate outraged justice, to sustain liberty and to safeguard the basic principles of civilisation'. ${ }^{6}$ Such heroisation far exceeded acknowledgement of the survivors, except perhaps in Australia where returned soldiers often received recognition along with the dead. 7 The recording of individuals' names upon war memorials was an ancient Greek practice of attributing fame in a permanent object of demarcation. This was not just a democratic gesture, but also a way of aggrandising the individual soldier's commitment to the collective, through his own death. Modern war memorials, however, described every soldier's name reflecting the nature of mass warfare and mass death, but also the democratizing of the very concept of noble heroism. The 
postwar importance, then, of the material object in contributing to the soldier's renown was a significant development of the warrior myth and the Homeric principle of fame accorded to those who achieved a 'beautiful death'.

The idea of the 'beautiful death' was expressed in modern images of dead soldiers, whom appeared to be sleeping. The restful repose was designed to cushion the reality of death for mourning families. George Lambert's sculpture for the St Mary's Cathedral Memorial in Sydney, for example, is no dead young soldier, as the title Recumbent Figure (1930) implies. ${ }^{8}$ Rather he lies sleeping, silent and noble. Adapted to Christian purposes, the 'beautiful death' is projected from polished bronze surfaces, and the hero literally shines in demonstration of his warrior status. In other effigies of the 'beautiful death', such as the 'recumbent figure' on the Southampton Memorial (1920, by Edwin Lutyens), the dead body is perched high above so that the sleeping soldier is obscured. His face and body may never be seen, but his fame (and those of the eighteen hundred names inscribed onto the pylon) shall be the reward for the 'beautiful death'. Similarly at Rochdale, Lutyens' recumbent figure served the purpose of allowing the viewer to 'appreciate the beauty of the upper portion on which it rests'. In other words, the figure was not an end in itself, but rather a device to connect the beauty of the structure to the memory of the male body. This proved a powerful device to mourning communities. When Lutyens was thinking about appropriate architectural forms, his mind turned to 'the abstract shape and intrinsic beauty' of classicism. ${ }^{9}$ Men who 'fell' in war should be memorialized for their beauty and glory, summed up in Lutyens invention of the phrase the glorious dead' which was placed on many memorials. His respect for the classical tradition reflected older visions of war and death. Classical monuments replaced the brutalised and mutilated with a heroic treatment of bodily beauty, and tied it to a myth of serenity so important for peacetime and recovery.

In his design for the original London cenotaph, Lutyens was said to have synthesized 'classical virtues' with the 'local idiom'. Whilst he 'took pure form, moulded it in the subtlest proportion and set in geometrical relation', the perfect formulation of this approach appeared in the war monument as none other. ${ }^{10}$ The modern cenotaph was an empty tomb. It did not contain bodies. At the same time, it represented the male body by resonating closely with the corporeal context that produced it. A cenotaph, in one sense, attempts to avoid any relationship to the very human flesh it memorialises. ${ }^{11}$ When cenotaphs incorporated coffins or dead bodies, as Lutyens did at Southampton or Manchester, they were perched at the very top, well out of reach of human gaze. Even then, the cloth of the greatcoat carved from stone usually covered their bodies and tin hats often covered men's faces. That men's bodies were killed in war was not a visual reality that the architect or sculptor wished to remember in stone. However, on many levels, especially the ceremonial, the relationship between bodies and war was impossible to erase. Soldiers referred to 'resting places' with an irony that noted the discrepancy between the reality and representation of death. As one German soldier remarked:

The battlefield is really a huge cemetery ... [with] innumerable little white crosses everywhere ... And then you can read in 
the paper 'Peacefully they rest' ... And nobody says that the enemy keeps shooting and the shells hit the heroes' grave, that the bones are squirted away with the mud ... where the heroes resting place was .... ${ }^{12}$

The notion of dying restfully or peacefully is the exact opposite of what occurs in violent conflict. This critical observation reflected Siegried Sassoon's feelings about the Menin Gate and its appeasing classicism. In his poem, On Passing the New Menin Gate, he decried its classicism as a 'pile of peacecomplacent stone' ${ }^{13}$ Far from giving him comfort, classicism made him angry. Abhorring the rhetoric of reconstruction that seemed to appease many people, he saw the grief of the bereaved being exploited in order to alleviate the government of moral guilt for the war. For Sassoon, programs of classical architecture anaesthetised people from the scars of war. The beauty and grandeur of classicism toyed with memory, especially the memory of the body's demise. Beautiful structures of civilised reconstruction and geometric cemeteries with ordered gardens combined to create the spatial evocation of the 'beautiful death'. It was a classical mythology that could alternatively comfort and offend in its highly modern insistence upon transformation from the horrible and degraded to the heroic and perfect.

Against the mythology of the 'beautiful dead' were the monstrous living. Mutilated soldiers certainly did not feel comfortable wearing their deformities like badges of honour. The classical body exuded a perfection that real soldiers could not necessarily live up to. In comparison to the masculine beauty of death, then, the evocation of Peace, although feminine and recuperative, appeared to be much less glamorous. There were, however, other important exceptions that delivered ambiguous messages about the gendered nature of death and the rebirth of civilisation. Inside the Anzac Memorial in Sydney, the tragedy and reality of death were portrayed in Rayner Hoff's centrepiece, The Sacrifice (1931-34). The three females figures (caryatids of wife, mother, sister) holding the shield above their heads with a dead, emaciated soldier across it, reference the Spartan mothers recorded by Plutarch. Hoff's supporters saw the sorrowful women as the 'emotionalisation of form'. ${ }^{14}$ This aspect of commemorative architecture was a key reason for his use of classicism. Just as the Greeks had developed symbolism and myth in the representation of war, Hoff used classicism as an allegorical construct. Although they are standard classical female types, they reference the myth of the Spartan mothers bidding their sons not to return without victory, unless lying dead upon their shields. Hoff's figures could be construed as a chilling reminder of women's 'support' for the war, such as in the Anzac Fellowship of Women and in the campaign for conscription. If one is aware of Plutarch's alarm at the power Spartan citizen women had within its polis, the classical symbolism takes on a rather critical view of women's incitement to heroic mythology. Indeed, as Ken Inglis points out, Australian women were more likely to join the imperially patriotic National Council of Women, than peace groups, and a majority of Australian women voters supported conscription in the referenda of 1916 and $1917 .{ }^{15}$

Furthermore, the voluntary nature of the Australian citizen soldier added to the pathos of The Sacrifice. Even in his vulnerable state, the masculinity of his 
sacrifice was still asserted. The architect, Bruce Dellit, thought the emaciated soldier was appropriately masculine. He also only wanted women represented in support roles, showing that war was really the business of men. ${ }^{16}$ Perhaps for Dellit only a truly masculine man could make such a sacrifice. ${ }^{17}$ Contrasting with the male figure's passivity, however, is the strength that the women possess in order to carry him above their heads. ${ }^{18}$ The official program of the memorial praises the 'Women of the State' for their support of the Memorial and their efforts during the war. It is clear that the caryatids are a tribute to women's sacrifices as well. ${ }^{19}$ Women's capacity for sacrifice is described as 'the beautiful quality of womanhood'. At the same time, women were praised for their de facto role only. By association, and in passive roles, women 'with quiet courage and noble resignation bore their burdens, the loss of sons, husbands and lovers. ${ }^{20}$ And yet the support of the female figures shows a partnership of male and female sacrifices. This partnership inflects wider debates about the status of the returned soldier, as well as women's claims to citizenship in postwar societies. ${ }^{21}$ If we compare this figure of dilapidated masculinity with the colossal male figures on the exterior, we find a different picture again. The columns that rise around the outside of the Anzac Memorial hold up these colossal square figures. ${ }^{22}$ Interestingly, the columns alleviated C.E.W. Bean from worrying about the overtly geometric nature of Rayner Hoff's sculptural figures. In his view, the columns' reference to classicism was more fitting for the sacred nature of the memorial, and the representation of the warrior's robust masculinity.

Typically, then, the masculinity of war was memorialised through the male body, and Death was largely a masculine event in monuments. ${ }^{23}$ Allied to this, however, was the accompanying image of Peace as symbolically feminine. ${ }^{24}$ Female figures, derived from ancient Greek Nikes, were regularly selected as literal figures of Peace. In the Thornton Memorial (1922, Yorkshire) by Harold Brownsword, the figure in ancient Greek dress holds up two wreaths, and is herself a personification of Peace. She is not a Nike, has no wings, but is classicised in her costume and contraposto limb, which is slightly revealed through the drapery. Although most women were involved in war work, nursing or voluntarism, and many women did not join pacifist organisations, the continued belief in women's natural peacefulness imbued the representation of classical figuration in war memorials. ${ }^{25}$

Nikes were poignant figures in war memorials. ${ }^{26}$ The traditional use of the Nike was as a literal emblem of victory and triumph. Warriors were her protégés, whom she guided to realise their noble desires for military success. The Nike was a goddess with little connection to the cycle of human life and frailty. ${ }^{27}$ In contrast, First World War memorials more often incorporated the figure as a symbol of the concept of peace, appropriating contemporary beliefs about women's biological characteristics. ${ }^{28}$ The modern Nike, was characterised, personalised and individualised by virtue of giving her the capacity to feel emotions, to suffer, to empathise and to grieve. The monumentalised Nike reflected the bodily services of women - she was now procreator, incubator, with her colossal and spacious womb, and her exposed breast ready for suckling. The transformation of the Nike reflected the 
population politics of postwar reconstruction. ${ }^{29}$ No longer a vengeful goddess, then, the Nike became a figure of Peace, made more human by her essentialised womanhood. This linked femininity and maternity to women's roles in the future reconstructed society. Often crowning pylons, Nike figures appeared in windswept Greek dress, striding steadily forward, not so much in boastful victory but with confidence in the future. In one Flanders memorial, she was embraced as an effigy of the martyred nurse, Edith Cavill, whilst others imagined her as an 'Angel of Victory'. ${ }^{30}$

This was no coincidence, as classical female figures could be interpreted as nurses. Typically, the role of nurses was conflated with motherhood and the feminine functions of comforting and grieving, as Margaret Darrow's study of French volunteer nursing points out. ${ }^{31} \mathrm{~A}$ French monument such as Henri Jean Moreau's Libourne (Gironde) memorial has a Nike attending a dead poilu wrapped in a blanket. In France it seems that nurturing Nikes were more commonly represented than nurses. ${ }^{32}$ Why an allegorical rather than literal reference to the role of nurses was more acceptable was part of a general disregard of nurses' roles in war, which was bound up with the masculinity of French national identity. Most nurses experienced a diminished status, which was reflected in war memorials. In Australia, the Anzac Memorial did not even attempt to distinguish between mothers and nurses. The Army Medical bas relief was described as depicting 'one of the noblest phases of the war - weary and wounded men tended with loving care by the Mothers of the race - here is to be seen a Matron, and two of her charges' ${ }^{33}$ While nurses struggled for the respect of their medical peers, their mass presence did make a cultural impact. Nurses are a major subject of paintings and war literature, and indeed many nurses became writers themselves. Given the continued reference to their natural qualities as nurturers of the nation's (male) children, for example, this might be seen as an accomplishment. Nurses' memoirs, poetry, and novels form a genre of literature in much the same way as soldiers' and surgeons' writings. They too created their own traditions and mythologies through the written word. Much of their focus reflected their struggle for professional recognition, rather than being treated as carers in uniform, which women were apparently more naturally disposed to. ${ }^{34}$

One aspect of nurses' writing that requires more scholarly attention is their knowledge of, and attitudes toward, the male body, and to different kinds of disabilities and their gendered meanings. Suffice to say for the purposes of this essay, that their observations of the male body reflect a cultural preoccupation that was unprecedented in Western history. It is significant, then, that modern depictions of a warring figure such as the ancient Nike, depict her as a nurse or, in keeping with the gendered assumptions about nursing, a mother. In England, the Folkestone Memorial has a female in ancient Greek dress holding a colossal wreath of peace and a Union Jack at half-mast. The designer, Ferdinand Blundstone, intended it to be a representation of Motherhood, but the figure also embodied the nation and thus the national sacrifice. It is not a homage to women's sacrifices in particular, but a gendered representation of the national meaning of war and a symbol of the importance of women in reproducing children that 
would be the hope of the future. Similarly, Blundstone's Stalybridge Memorial, (Cheshire, 1921) presents a Nike or Angel of Peace attending a collapsed Tommy. Bare and youthful breasts portray an inescapably erotic relationship. Appropriating the bare breast of the Nike of Paionios (Olympia), such monuments do not represent the ecstasy of flight, but rather the natural connection between sex and life, succour and rebirth. Barebreasted nurturing returned sexuality to procreation. The mother figure combined with the Nike became an image of military assistance as well as societal replenishment. The overt maternalism is further revealed in the fact that the surplus raised in donations was put in a fund for the children of the dead.

Gendered perceptions informed the deployment of the Nike in war memorials, transforming her from a perfunctory military symbol to a feminine one. More than that, though, she was no longer a benign figure representing a grand tradition, but came closer to her meaning in ancient Greek civic religion she was returning to her former status as a socialised personality. Although that personality was not understood in terms of religious privilege, as gods and goddesses were in ancient times, she was instead imbued with the personality of a mortal. The grieving, nursing, maternal Nike of commemorative architecture in the 1920s and 1930s is a modern phenomenon that reflects the 'emotionalisation' of the war monument, and the transition from effigy of imperial victory to 'site of mourning'. This was instead of females being seen as active participants in war. The female embodiment of Peace, and the male embodiment of War, in memorials reflected ideas about men and women as partners in life, and therefore with defined roles based on gendered identities.

There were, however, some powerful contradictions to the masculine enterprise of war, and the view that women need to be protected. For the Nike, as symbolic mother of history and the future, was sometimes produced with a muscularity that betrayed her as a physical force, a protector of men. In the Blois War Memorial (Loir-et-Cher, 1923), two stone winged Nikes hold above their heads a coffin that symbolically contains within it the bodies of all the men who are named on its pylon. Their strength is revealed in bare arms and their wings, which help to support the coffin. In his dedication speech at the inauguration of the memorial, the symbolic importance of the wings of the Nike was not lost on the local mayor. Questioning the very process of commemoration, and fearing the evaporation of war's meaning, he asked, 'Are all the words we have just uttered only words, will they fly away forever? ${ }^{35}$ The Nike as an emblem of flight, then, symbolised the fear of memory's disappearance. The fleeting temporality of the mourning process is evoked through the Nike, and yet her stony construction in the form of the monument helps to ground her, to enforce her permanence and endurance in the earthly realm. The flight of the Nike is dualistic. Wings imply the passing of time, the healing of wounds, the forgetting of pain and the recovery of society, and yet her material form makes her anything but light and temporal. Despite her wings, the modern Nike cannot escape the past. With the heavy burden of history, then, she embraces the future, a future in which her role as 'mother protector' is placed as a central component in the continuance of Western civilisation. 
There were also some radical attempts to invert the gendered ordering of memorialisation. Rayner Hoff's sculptural group entitled The Crucifixion of Civilisation 1914 (1932) was rebuked for its explicit evocation of the bloody horror of the war. Rather than a grieving or nurturing Nike, Hoff's central figure was a naked crucified woman. No discrete folds of classical chemise, this female is woman stripped and tortured, contradicting the mythology of masculine and Christian heroism in war. Her sexualised and morbid body was an affront to the gendered construction of war as a male domain involving male courage and sacrifice. This female Jesus positioned woman as a central figure, and therefore both an active participant and an active sufferer of pain. She was no support act to the main masculine event. As I have already noted, the idea that 'woman' was the embodiment of 'peace', 'civilisation' or 'humanity' drew upon popular maternalist ideas. ${ }^{36}$ The problem with Hoff's sculpture was that if Civilisation was female, then the responsibility for its reconstruction might be seen as women's. Representation had powerful meanings beyond the realm of the symbolic, but linked the imagined allegorical world with the bodies, lives and sex roles of real women. Biological duty was in danger of being misconstrued as a sacrifice. Surely sacrifice was the preserve of Christ and the warrior heroes of the war? Moreover, if women were represented as the rebuilders of Western civilisation, a subversive representation of female power and leadership would have contradicted the need for women to leave their employment and return to more or less domestic pursuits. Given postwar debates over female citizenship, indirect rights rather than representative roles, this metaphor of partnership was politically useful. ${ }^{37}$ Officially rejected, Civilisation lost the power of representation to the importantly male figure of Sacrifice that continues to stand in the Anzac Memorial today. Hoff still managed to be subversive, however, and it is fascinating to consider that an emaciated soldier was, in comparison, more appealing. The authority of classicism in the Sacrifice was preferable to a figure of a naked woman brutalised on the Christian cross. Arguably, hygienic classicism wiped away all the messy sexual and biological connotations bound up with the naked female body.

To conclude, then, the gendering of death as masculine and peace as feminine in war monuments was complex. On the one hand, it affirmed gendered codes of behaviour and stereotypical roles. On the other hand, some architects and sculptors engaged with the themes of war and death in an exciting, ambiguous and unconventional manner. The flexibility of the modern interpretation of classical aesthetics enabled these ambiguities. The classical motif channelled social commentary and personal politics without seriously offending commissioners of public works. Whether a sleeping warrior, a Nike or Angel of Peace, classical beauty was employed to diffuse the traumatic memory of war, providing instead highly gendered evocations of death and renewal as a partnership. War and Peace were naturalised as a marriage of classical figures, as visions of wholeness and restoration, and therefore proposing a traditional gender order in a time of social and bodily fragmentation. 


\section{ENDNOTES}

1 Alan Borg, War Memorials From Antiquity to the Present, Leo Cooper, London, 1991, p. 15.

2 Jay Winter, Sites of Memory, Sites of Mourning: The Great War in European Cultural History, Cambridge University Press, 1995, p. 233.

3 The idea is Judith Butler's, who argues that gender may be considered as a 'corporeal style' or an 'act' which is both intentional and performative. This 'suggests a dramatic and contingent construction of meaning'. Then the relationship between objects, discursive and individual practices is allowed a life, an embodiment, a staging. War monuments interact with ideas about embodiment and are also highly staged in ceremonial practices of inauguration, dedication and remembrance activities. In Judith Butler, 'Bodily Inscriptions, Performative Subversion', Gender Trouble: Feminism and the Subversion of Identity, Routledge, London, 1990, p. 33. See also her essay 'Performative Acts and Gender Constitution: An Essay in the Phenomenology of Feminist Theory', in Katie Conboy (ed.), Writing on the Body: Female Embodiment and Feminist Theory, Columbia University Press, New York, 1997.

4 Pierre Nora, Realms of Memory: The Construction of the French Past, 1, 'Conflicts and Divisions', Translated by Arthur Goldhammer, Columbia University Press, 1996.

5 Jean-Pierre Vernant, 'A “Beautiful Death" and the Disfigured Corpse in Homeric Epic', in Froma I. Zeitlin (ed.), Mortals and Immortals: Collected Essays, Princeton University Press, New Jersey, 1991, pp. 50-51.

6 In Ambrose Pratt, The National War Memorial of Victoria: An Interpretative Appreciation of the Shrine of Remembrance, W.D. Joynt, Melbourne, 1934, p. 9.
7 K.S. Inglis and Jock Phillips, 'War Memorials in Australia and New Zealand: A Comparative Survey', in John Rickard and Peter Spearritt (eds), Packaging the Past? Public Histories, Special Issue of Australian Historical Studies, Vol. 24, No. 96, April 1991, Melbourne University Press, Melbourne, p. 186.

8 Originally Lambert titled it Dead Soldier, and aimed at combining a vision of sainthood with an Australian digger. However, the use of the term 'Recumbent' superseded this. See Ken Inglis, Sacred Places: War Memorials in the Australian Landscape, Melbourne University Press, 1998, p. 169. See also J.C. Waters in his 1932 survey of AIF burials, poignantly subtitled 'Where They Sleep', in part three of his book, Crosses of Sacrifice: The Story of the Empire's Million War Dead and Australia's 60,000, Angus and Robertson, Sydney, 1932, p. 113.

9 Lutyen's words cited in Christopher Hussey, Life of Sir Edwin Lutyens, London, 1950, p. 375.

10 A.S.G. Butler, The Lutyens Memorial: The Architecture of Sir Edwin Lutyens, Vol. 3, Country Life and Scribners, London and New York, 1950, p. 37.

11 There are notable exceptions, such as the Croydon Memorial, where two bronze figures attached at the base, one of which is a wounded soldier bandaging his own arm. The other figure is a young woman with a child who seems to be desperately reaching out to the soldier on the opposite side of the cenotaph. It is inscribed as 'A tribute to the men and women of Croydon who died and suffered'.

12 Philip Witkopp (ed.), Kriegsbriefe gefallener Studenten, Munich, 1928, p. 129; Bernd Huppauf, 'War and Death: the experience of the First World War', in Mira Crouch and Bernd Huppauf (eds), Essays on Mortality, University of New South Wales, Kensington, 1985, p. 70. 
13 Unveiled in 1927, Sassoon wrote of the Menin Gate, that is was ' a pile of peacecomplacent stone...well might the dead who struggled in the slime/ Rise and deride this sepulchre of crime'. In Gavin Stamp, Silent Cities: An Exhibition of the Memorial and Cemetery Architecture of the Great War, Royal Institute of British Architects, London, 1977, p. 4.

14 Earl Beauchamp, Howard Ashton, E.C. Temple Smith and W.Bede Dalley, Rayner Hoff, Sunnybrook Press, Sydney, 1934, p. 2.

15 Ken Inglis, 'Men, Women and War Memorials: Anzac Australia', Daedalus, (Learning About Women: Gender, Politics and Power), Fall 1987, Vol. 116, No. 4, p. 55.

16 Cited in Inglis, 'Men, Women and War Memorials', p. 45.

17 Waters, Crosses of Sacrifice, pp. 9-10.

18 The German artist Kathe Kollwitz repeated a similar gesture in the memorial to her son. See Regina Schulte, 'Kathe Kollwitz' Sacrifice', (transl. by Pamela Selwyn), History Workshop Journal, 41, Spring 1996, pp. 195-196. Kollwitz' emphasis on the raising of the dead son to show that the sacrifice was as much the parents' as his own, recalls Rayner Hoff's Sacrifice which honours the sacrifice that women made by giving sons, lovers, brothers and husbands in service of the State and the 'Mother Country'.

19 S. Elliott Napier (ed.), The Book of the Anzac Memorial, Beacon Press, Sydney, 1934, p. 37.

20 The Anzac Memorial, Hyde Park, Sydney, NSW, no date, official publication, p. 7 .

21 See Susan Grayzel, Women's Identities at War: Gender, Motherhood and Politics in Britain and France During the First World War, University of Northern Carolina Press, Chapel Hill, 1999.
22 Deborah Edwards, This Vital Flesh': The Sculpture of Rayner Hoff and His School, Art Gallery of New South Wales exhibition catalogue, Sydney, 1999, p. 55.

23 See Nancy Huston, 'The Matrix of War: Mothers and Heroes', in Susan Suleiman (ed.), The Female Body in Western Culture, Cambridge University Press,

Cambridge, 1986, pp. 119-136.

24 A notable exception is in the Welsh National War Memorial (1928), which has a naked youthful male bronze personified as Messenger of Peace. See Derek Boorman, At the Going Down of the Sun: British First World War Memorials, Ebor Press, York, 1988, p. 160.

25 Joyce Berkman, 'Feminism, War and Peace Politics: The Case of World War I', in Jean Bethke Elshtain and Sheila Tobias (eds), Women, Militarism and War: Essays in History, Politics and Social Theory, Rowman and Littlefield, Savage, Maryland, 1990, pp. 141-160.

26 They appear to be more common in Europe than Australia. See Inglis, Sacred Places, p. $172 \mathrm{ff}$.

27 Marina Warner, Monuments and Maidens: The Allegory of the Female Form, London, 1985, p. 131.

28 Notable exceptions include York and Lancaster Regiment Memorial, Sheffield, which has a tall bronze Nike with two soldiers. One holds a revolver, the other a rifle. The paraphernalia of war is also depicted, such as weapons, ammunition box, helmet and drum. See also the representation of Patriotism as Athena Parthenos in the Calverley Memorial, Yorkshire, 1922. The giant Nike at Le Havre (Seine-Maritime), by M. Poisson, 1921, is represented along with combat, the vanquished soldier and the family. In Australia, the Winged Victory (Marrickville, New South Wales, 1919, by Gilbert Doble) holds a wreath of peace in one hand but raises a sword in the other. 
29 Susan Grayzel, Women's Identities at War: Gender, Motherhood and Politics in Britain and France During the First World War, University of North Carolina Press, 1999. See also Mary Louise Roberts, Civilisation Without Sexes: Reconstructing Gender in Postwar France, 1917-1927, University of Chicago Press, Chicago and London, 1994.

30 Rose E.B. Coombs, Before Endeavours Fade: A Guide to the Battlefields of the First World War, Battle of Britain Prints International, London, 1976, p. 18. In contrast to Mont Noir, the memorial to Edith Cavell near Trafalgar Square combines modernist simplicity, nineteenth century feminine morality (Cavell's dress and posture) and medieval Christianity (figure of the Madonna and child seated atop the Christian cross). It describes the characteristics of a dutiful nurse in the genre of Christian servant and religious martyr. Inscribed on the monument are the words 'Humanity, Sacrifice, Fortitude and Devotion'. Dualistically, there is the inscription, 'For King and Country', which was later added along with Cavell's own words, almost in contradiction of that statement; 'Patriotism is not enough. I must have no hatred or bitterness for anyone'. Arguably, it was a statement of forgiveness and healing over nationalist rhetoric. It is interesting that this memorial directly refers to Cavell by providing an effigy of her, whereas the Mont Noir memorial uses the Nike as an allegory of peace, and there is no reference to her execution at all. Cited in Boorman, Before Endeavours, p. 6.

31 Margaret H. Darrow, 'French Volunteer Nursing and the Myth of the War Experience', American Historical Review, Vol. 101, No. 1, February 1996, pp. 80106.

32 Darrow, 'French Volunteer', p. 83.

33 The Anzac Memorial, p. 13.

34 See Anne Summers, Angels and Citizens:
British Women as Military Nurses, 18541914, Routledge \& Kegan Paul, London, 1988; Julia Hallam, Nursing the Image: Media, Culture and Professional Identity, Routledge, London, 2000.

35 Marcel Bernard, 1923, cited in Sherman, Construction of Memory, p. 308.

36 See for example, Charles Jagger's 'Humanity' in the Hoylake and West Kirby Memorial.

37 See Ilene Rose Feinman, Citizenship Rites: Feminist Soldiers and Feminist Antimilitarists, New York University Press, New York and London, 2000. 